\title{
DISCOLORATION AND DECAY ASSOCIATED WITH HARDWARE INSTALLATION IN TREES
}

\author{
by Brian C.P. Kane ${ }^{1}$ and H.D.P. Ryan III $^{2}$
}

\begin{abstract}
Tree support systems have been used for many years to help reduce the risk of tree failure due to weak and split crotches and from cracks in branches and trunks. Because any wound that breaks the bark of a tree initiates the decay and compartmentalization processes, new tree support systems have been designed to eliminate the need to drill holes into a tree during installation. Recent research suggests that the new systems do not injure tree parts as much as drilling holes, because drilling wounds the tree. A sample of 20 bolts of wood that had hardware previously installed was collected from arborists throughout the northeastern United States. The samples received came from trees regarded as good compartmentalizers. Simple measurements and visual analysis indicate that decay and discoloration directly attributable to hardware installation appear not to be as severe as expected (even after 37 years in one sample). More quantitative research into physiological and mechanical aspects of tree support systems is needed to assess each system's utility for arborists.
\end{abstract}

Key Words. Decay; cabling; hardware installation.

Arborists have installed hardware into trees for many years in an attempt to reduce the risk of failure associated with a weak crotch or crack in the tree trunk (Mayne 1975; Felix and Shigo 1977; Campana 1999). The current edition of the ANSI A300 standard (Part 3, Support Systems a. Cabling, Bracing, and Guying) (A300) states: "Support systems are used to provide supplemental support to leaders, individual limbs, and/ or the whole plant ..." (ANSI 2000). The two basic types of hardware arborists install in trees to provide supplemental support are cables and braces (or rods). Guying generally is used with newly planted trees, although windthrown mature trees occasionally can be righted and guyed. Within each type of support system (cables and braces), two methods of installation are possible: "dead-end" and "through." Dead-end hardware means that the anchor in the tree (a lag hook or wood rod) enters one side of the branch or trunk and does not exit the opposite side. For dead-end hardware, installation holes should be drilled $1 / 16$ to $1 / 8$ in. (1.5 to 3.0 $\mathrm{mm}$ ) smaller than the diameter of the anchor (ANSI
2000). In contrast, "through" hardware is installed completely through the tree. A hole is drilled entirely through a trunk or branch, a bolt is installed, and a washer and nut on the opposite end of the bolt secure it in place. For through-hardware, installation holes should be drilled no more than $1 / 8$ in. larger than the diameter of the hardware to be installed (ANSI 2000).

The A300 standard also states that dead-end hardware should be used in sound wood only. Furthermore, the standard states that when installing through-hardware, washers should not be countersunk into the wood (ANSI 2000). The first recommendation is consistent with prior practices, because installing a lag into decayed wood breaches wall four of compartmentalization and increases the spread of decay around the lag (Felix and Shigo 1977; Shigo and Felix 1980). In theory, the spreading decay increases the probability that the lag may pull out of a severely decayed stem or branch. The authors' observations over a combined 40 years in the field show lag pullout to be exceedingly rare. Not countersinking washers is a change from past practices. In an early publication on the practice of installing hardware into trees, Thompson (1935, as cited in Mayne 1975) stated that washers should be countersunk to a depth of $1 / 8$ in. $(3 \mathrm{~mm})$ below the cambium. This recommendation was still the practice in the late 1970s and early 1980s when Felix and Shigo wrote two articles (Felix and Shigo 1977; Shigo and Felix 1980) on decay associated with hardware installation. Shigo (1983) recommended seating washers on the wood, not in the wood, and not on the bark. However, Smiley (1998) found that countersinking to a depth of $1 / 8$ in. into the xylem significantly increased the discoloration associated with hardware installation in American beech (Fagus grandifolia) and red oak (Quercus rubra).

Recent innovations in tree support systems include cabling systems that do not require drilling holes in stems. Instead, the new systems support codominant stems, weak crotches, or cracked stems by looping a synthetic web sling around each stem to be supported. In the Cobra system (Baumsicherungsprodukte, Stuttgart, 
Germany), a polymer rope passes through the web sling and thus around each stem; then each end of the rope is spliced back into itself after it passes around each supported stem (Figure 1). The double-belt System Osnabrück (now known as CrownTex $\odot$, Hinrich Meyerdiercks, Bremen, Germany) uses a belt mechanism to attach a web sling around each stem to be supported, and a conventional cable is set between the slings (Figure 2). The Cobra system and the double-belt System Osnabrück have been reviewed in detail elsewhere (Ball and Konda 2000; Brudi 2000; Stobbe et al. 2000). These systems, which were developed in Europe and have just been introduced into the United States in the last several years, do not require drilling trees to install lags or bolts.

Stobbe et al. (2000) report no adverse physiological effects of using the double-belt System Osnabrück on ten European beech (Fagus sylvatica) trees six years after system installation. In contrast, drilling holes in tree stems can

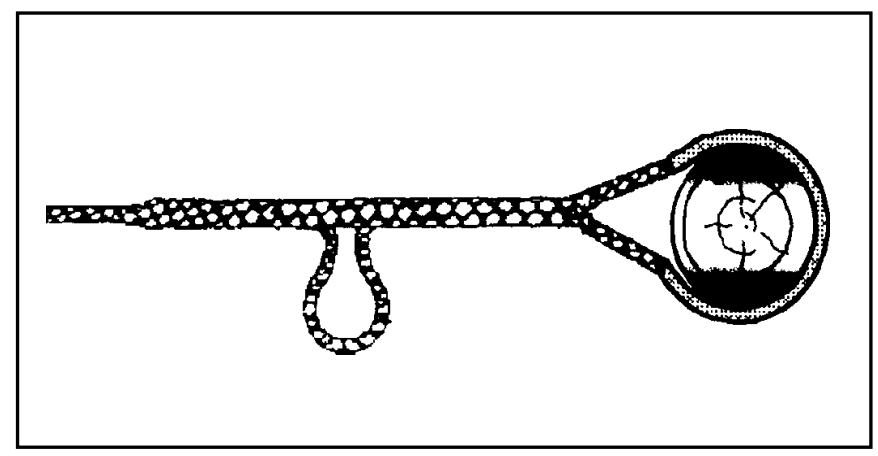

Figure 1. One side of Cobra system showing web sling around tree stem and support rope spliced back into itself.

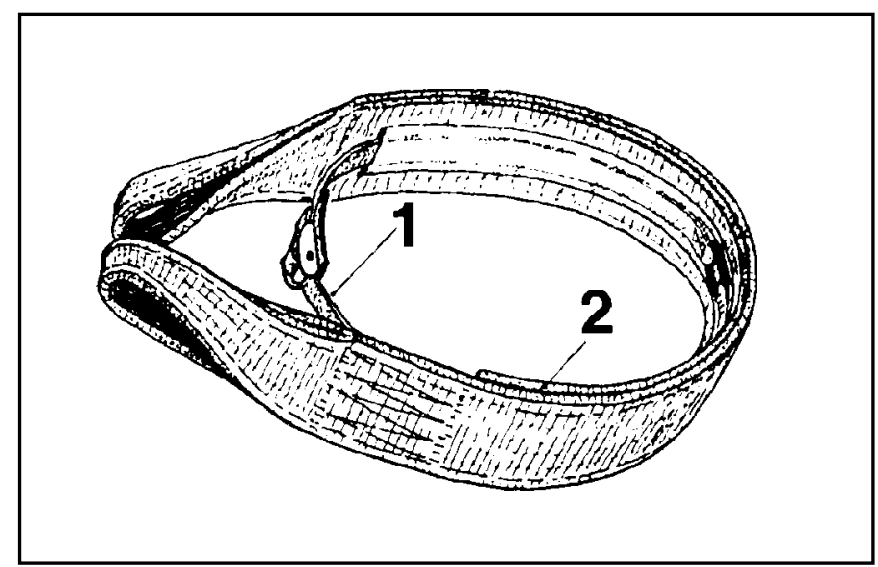

Figure 2. Double-belt System Osnabrück, showing inner belt to secure around tree stem and outer sling for attaching support cable (Stobbe et al. 2000). facilitate discoloration and decay. This effect is most notable in the longitudinal direction (Stobbe et al. 2000) because compartmentalization is weakest in that direction (Shigo 1979). Figure 3 (from Stobbe et al. 2000) shows significant discoloration and decay in a stem that previously had been drilled through. The discoloration and decay are seen in the longitudinal and radial directions and are directly associated with the hole that was drilled to install through-hardware. Figure 3 also shows that the hardware had been installed with countersinking of washers below the bark and into the wood, which has been shown to increase discoloration and decay in American beech (Fagus grandifolia) and red oak (Quercus rubra) (Smiley 1998). Drilling holes in a tree allows the decay process to begin, but the extent of discoloration and decay associated with the drilled hole is important to consider. Prior research shows that discoloration and decay directly resulting from properly installed dead-end and through-hardware usually are limited in cross-section (Felix and Shigo 1977; Shigo and Felix 1980). Several factors influence the degree of discoloration and decay, and the tree's ability to compartmentalize the wound.Tree genetics (Garrett et al. 1979; Shigo and Felix 1980); tree vitality; condition of wood penetrated by drill hole; time of year of installation; and the size, depth, position, and number of holes drilled all affect the tree's wound response (Felix and Shigo 1977; Shigo et al. 1977).

\section{MATERIALS AND METHODS}

In January 2001, the authors placed a request for help in the New England Arboriculture Quarterly (published by the New England Chapter of ISA). We asked New England arborists to provide samples of tree cross-sections that contained previously installed hardware. In response, we received 20 samples with both dead-end and throughhardware. The trees had been drilled as recently as a year prior to removal and as long as 37 years prior to removal. In all the through-hardware samples, the washers were countersunk into the wood; in three of the deadend hardware samples, the bark around the short end of the lag hook was disrupted during installation. Samples came from several tree species: Norway maple (Acer platanoides), white ash (Fraxinus americana), European beech, Norway spruce (Picea abies), eastern white pine (Pinus strobus), and red oak. All of the samples came from different trees except two white pine samples and two Norway maple samples.

For each rough sample we received, the end closest to the drilled hole was band-sawed as close as possible to 


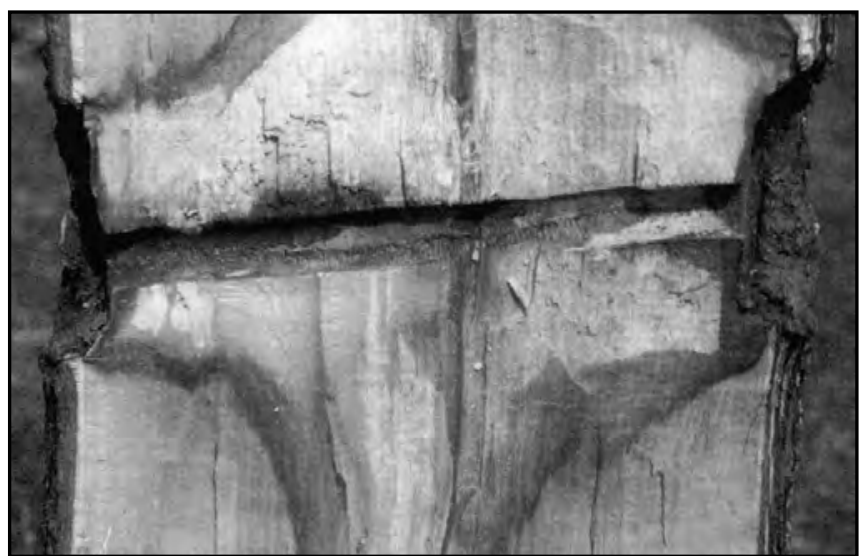

Figure 3. Longitudinal view of discoloration and decay extending from drill hole for hardware installation (note countersinking of washers into wood) (Stobbe et al. 2000).

the hardware. The end of the sample was then sanded with first a coarse- and then a fine-grain paper to present a clear finish for photographing. Six of the photographed samples were chosen to illustrate observations presented in this article. Photographs of the samples (Figures 4 through 8) were taken with a Nikkormat FT$\mathrm{N}$ camera using a $50-\mathrm{mm}$ Nikon ED lens (f/2.8, shutter 1/60 sec) and Fujichrome Provia 100-speed slide film. The samples were placed on a photograph background and illuminated with low-intensity light projected at a 45-degree angle to the sample. Slides were scanned using a Minolta DS Elite Slide Scanner (input resolution 1,200 dpi, output resolution $300 \mathrm{dpi}$ ), and touched up to improve image clarity where appropriate. In no case did touching up the image change the appearance of discoloration and decay in a sample, nor did it change the appearance of the nondiscolored wood. Touching up was used only to enhance image reproduction quality. In each photograph, one can clearly discern whether discoloration is present and associated directly with hardware installation, as well as the extent of such discoloration. We only examined the samples visually.

In all cases, the longitudinal distance from the drilled hole to the cross-section surface was not more than 2.5 in. $(6.35 \mathrm{~cm})$; in some cases the distance was less than $1 \mathrm{in}$. $(2.54 \mathrm{~cm})$. The following data were collected for each sample: tree species, diameter (outside bark), axial distance from drill hole to cross-section surface, age of stem, number of years since hardware was installed, type of hardware, whether washers were countersunk into the wood, and presence and extent of discoloration and decay directly attributable to hardware installation. The number of years since hardware installation was determined by counting growth rings from the extent of discoloration associated with hardware installation. The extent of discoloration was determined in most cases by ruler measurement, because the discoloration associated with hardware installation for the most part conformed to an easily measured shape. In some cases (Figure 5), discoloration and decay that appeared not to be directly caused by hardware installation was evident in stem cross-sections. We assumed that these areas were not directly caused by hardware installation and did not measure them.

\section{RESULTS}

Because of the small sample size $(n=20)$ and lack of experimental control, we did not perform any statistical tests. Another limitation of the study is that none of the samples came from trees generally recognized as weak compartmentalizers. The samples we collected came from trees usually considered good compartmentalizers. This point illustrates the need for further quantitative examination of the discoloration and decay associated with hardware installation because even within a species, ability to compartmentalize varies among different individual trees (Shigo et al. 1977). Of the samples we did receive, however, which covered eight different species and various sizes, ages, and growth rates, none showed a significant amount of wood decay directly associated with hardware installation (Figures 4 through 8 ). Figures 4,6 , and 8 show the effectiveness of walls two, three, and four in European beech, Norway maple, and eastern white pine. Of the 20 collected samples, all but two showed some discoloration. Both of the samples without discoloration, however, had been drilled within 3 years of being removed. The extent of discoloration in the cross-sections varied, as might be expected given different species, growth rates, and years since installation. On two trees that had been drilled more than 25 years prior (one was European beech, the other red oak-both regarded as strong compartmentalizers) (Shigo and Larson 1969), there was no wood decay associated directly with the drill hole. There was noticeable discoloration of the European beech (Figure 4) stem, but the wood itself was not soft to the touch. In contrast, on the stems where decay already existed, and the tree was not healthy, hardware installation appeared to expedite its spread across the stem cross-section (Norway maple \#6) (Figure 5). While Norway maple generally is regarded as a strong compartmentalizer (Santamour 1984), when the existing column of discoloration and decay was penetrated by 


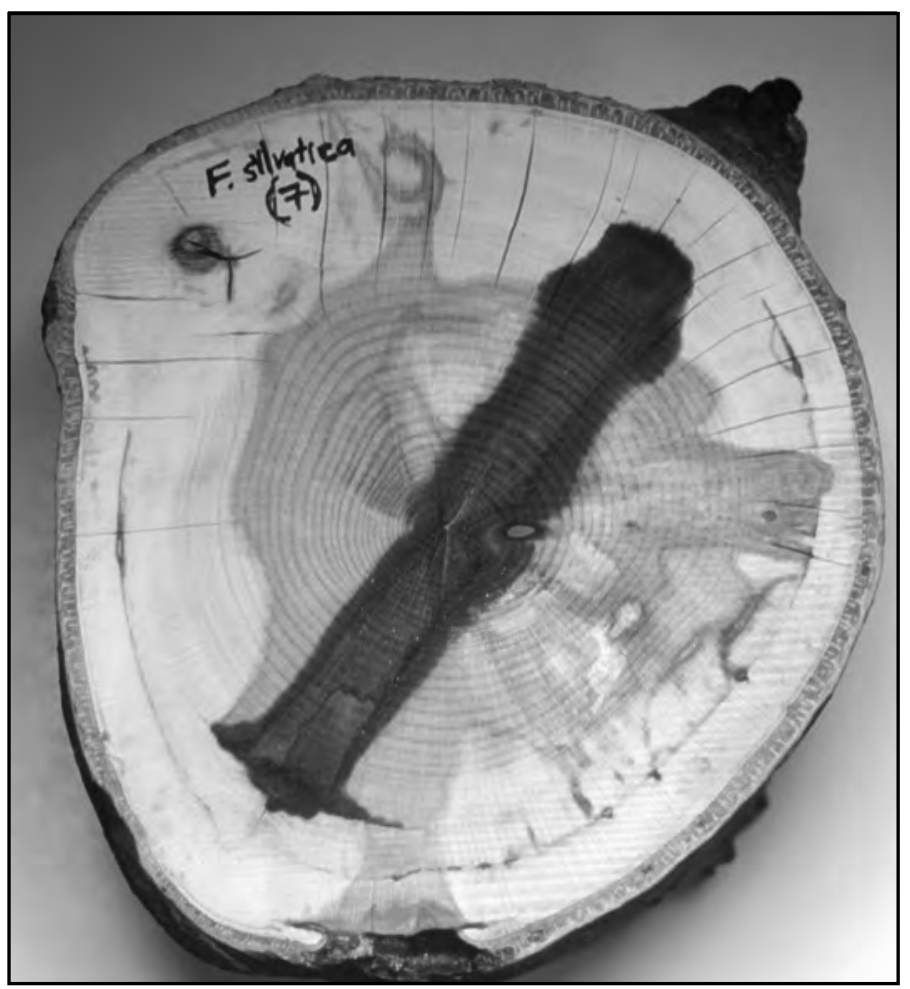

Figure 4. European beech showing discoloration associated with drilling a hole for through-hardware installation (29 years since installation). A more recent drill hole is evident at the bottom of the photograph: faint discoloration with the same shape as the dark drill hole discoloration.

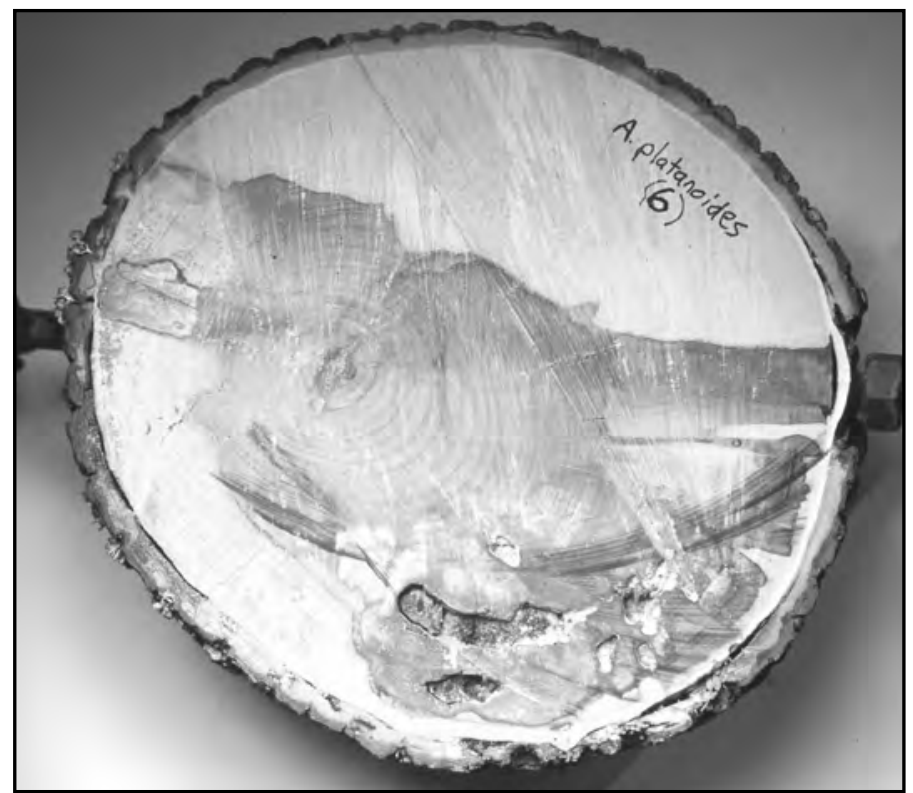

Figure 5. Norway maple showing advanced decay that spread more quickly as a result of drilling a hole for through-hardware installation ( 2 years since installation; branch died and decay continued). the drill hole, discoloration and decay spread quickly. It should be remembered, however, that this study was purely observational, and interactions between species, vitality, and genetics may influence rate and extent of discoloration in stems that have been drilled.

Examining cross-sections from stems drilled within 5 years of removal, the clearly delineated discoloration associated with the drill hole for through-hardware illustrates strong wound compartmentalization (e.g., Norway maple \#8 and \#9) (Figure 6). Both of these stems had been drilled 4 years prior, and one can visually determine the extent of discoloration associated with drilling. Wall four is sharply defined on each crosssection, indicating each tree's effective wound compartmentalization. This is not surprising because Norway maple has been shown to be a good compartmentalizer (Santamour 1984). Based on the relatively small extent of discoloration in relation to stem cross-sectional area 4 years after drilling, it appears that considerably more time would have to elapse before sufficient decay of the stem occurred to justify concerns of strength loss in the drilled stem (assuming the tree would continue to grow normally over the same amount of time and the rate of expansion of decay was relatively constant).

One red oak had been drilled 37 years prior to removal, and it stood as a testament to the tree's ability to compartmentalize wounds: There was no discoloration that extended past wall four (Figure 7). Interestingly, the large [2.25 $\left.\mathrm{in}^{2}\left(14.5 \mathrm{~cm}^{2}\right)\right]$, diamond-shaped washer was not countersunk below the bark during bolt installation on this particular tree, even though it was recommended practice at the time. On the other hand, two samples from the same white pine tree, where lags had been installed 19 years prior to removal, indicated initially unsuccessful wall four formation. This is shown by the faint discoloration that extends radially from the initial drill hole towards the lag (where the callus has grown around the lag and started to grow around the cable splice) (Figure 8). Four years prior to being removed, the tree successfully formed wall four, as shown by the lack of discoloration extending into the four most recent growth rings. In spite of the poor wall four compartmentalization, the total extent of discoloration associated directly with the drill hole is limited $(1.4 \%$ of the total stem area).

\section{DIscussion}

Tree support systems will continue to be a part of the arboriculture industry in the future. Preserving mature, 

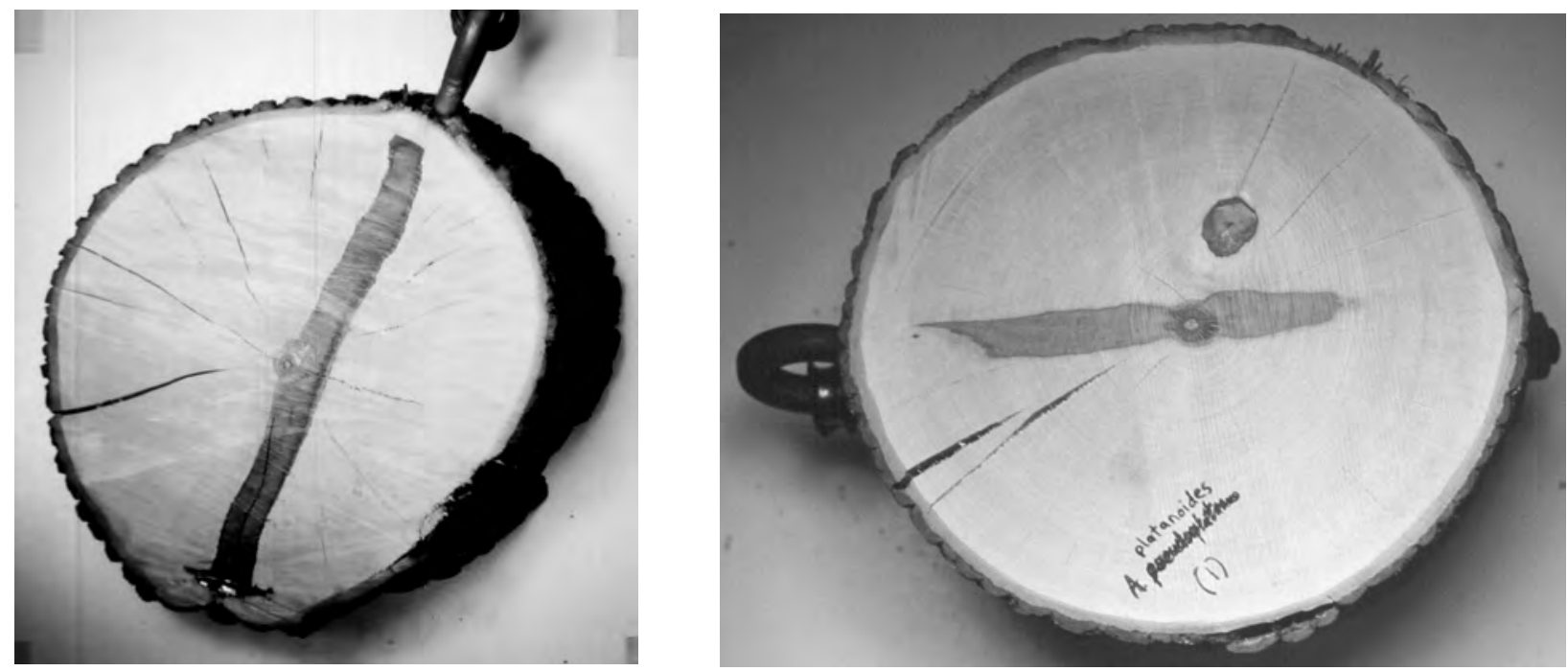

Figure 6. Two Norway maples showing well-compartmentalized discoloration associated with drilling a hole for through-hardware installation (4 years since installation).

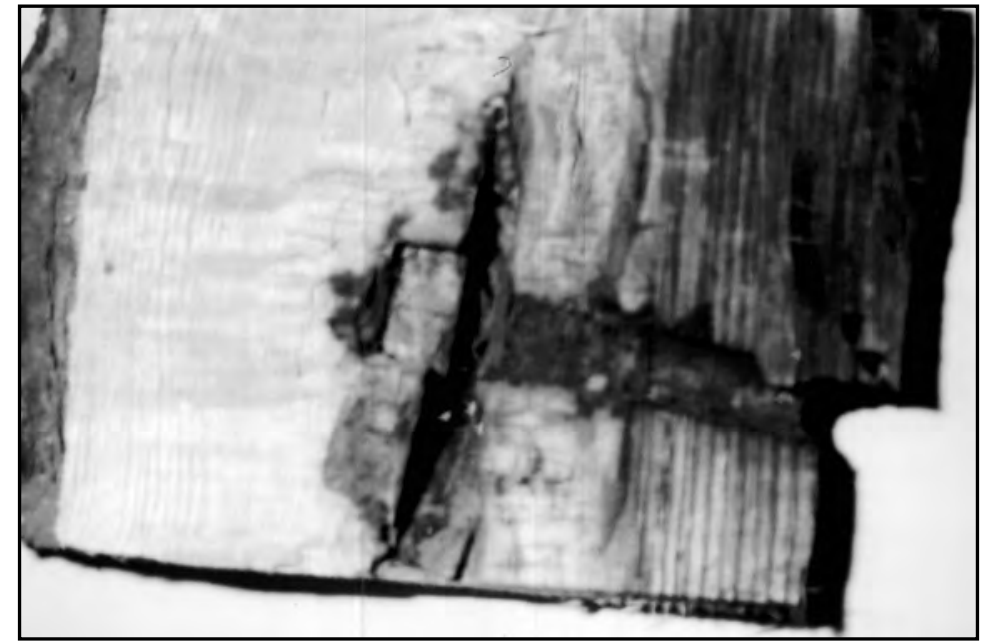

Figure 7. Red oak showing discoloration associated with drilling a hole for through-hardware installation (37 years since installation). Wall four prevented discoloration from extending into callus tissue, even though the nut and washer were not completely callused over for 8 years after the initial installation (compare Figure 8).

historic, or otherwise significant trees for clients is an important service arborists provide. Given the liability associated with tree failure and that weak or split crotches are an important structural defect (Matheny and Clark 1994), it is critical that support systems help reduce the likelihood of branch or whole tree failure. The adverse physiological consequences of installing hardware by drilling

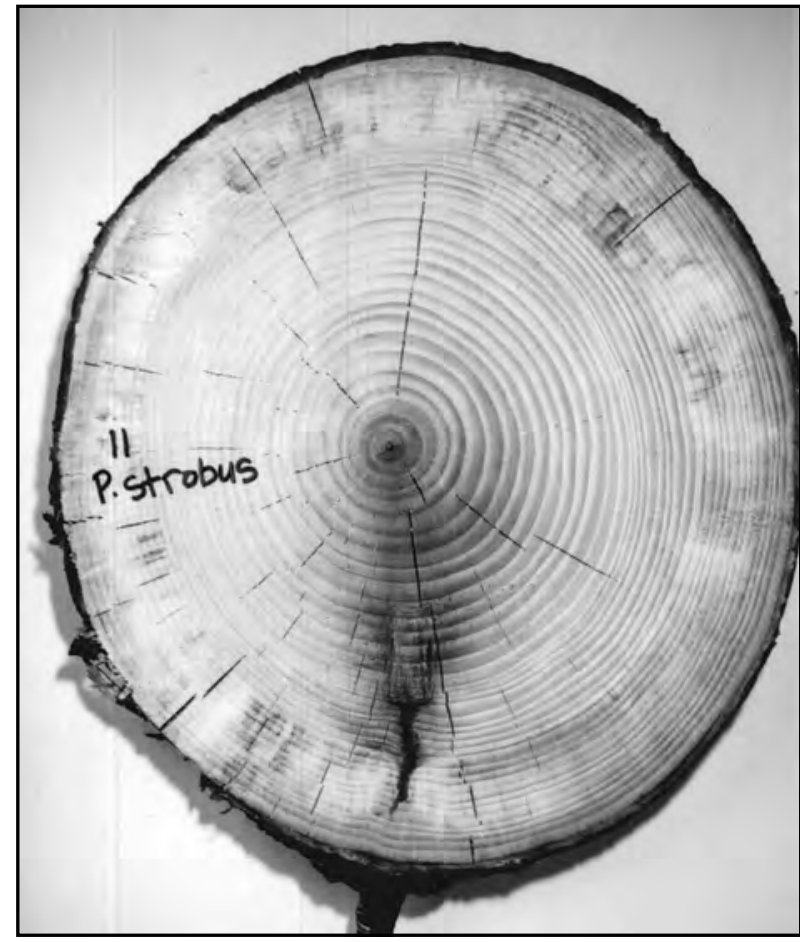

Figure 8. White pine showing discoloration associated with drilling a hole for dead-end hardware installation (19 years since installation).

holes in trees cannot be overlooked because any wound forces the tree to reallocate resources to compartmentalize the wound. Arborists must weigh the trade-off of stabiliz- 
ing a weak or split crotch with the amount of physiological damage that will occur with drilling holes in the tree stem and branches. Based on earlier observations (Felix and Shigo 1977; Shigo and Felix 1980) and the sample of drilled branches and stem presented here, the threat of wood decay appears not to be significant in trees that are good compartmentalizers, as long as hardware is installed according to the A300 standard (ANSI 2000). Further study is needed to determine responses of other species of trees in a more controlled experiment that tests decay and discoloration associated with hardware installation in trees. In particular, species recognized as weak compartmentalizers should be examined.

\section{LITERATURE CITED}

American National Standards Institute (ANSI). 2000. American National Standard for Tree Care Operations-Tree, Shrub, and Other Woody Plant Maintenance-Standard Practices (Support Systems a. Cabling, Bracing, and Guying). American National Standards Institute, New York, NY.

Ball, J., and T. Konda. 2000. Cobra: An examination of an alternative tree support system. Tree Care Industry 11(3):8-16.

Brudi, E. 2000. Tree bracing: New systems, new techniques. Arborist News 9(4):45-47.

Campana, R.J. 1999. Arboriculture: History and Development in North America. Michigan State University Press, East Lansing, MI. 443 pp.

Felix, R., and A.L. Shigo. 1977. Rots and rods. J. Arboric. 3(10):187-190.

Garrett, P.W., W.K. Randall, A.L. Shigo, and W.C. Shortle. 1979. Inheritance of Compartmentalization of Wounds in Sweetgum and Eastern Cottonwood. Northeastern Forest Experiment Station, Broomall, PA. 4 pp.

Matheny, N.P., and J.R. Clark. 1994. Evaluation of Hazard Trees in Urban Areas (2nd ed.). International Society of Arboriculture, Champaign, IL 85 pp.

Mayne, L.S. 1975. Cabling and bracing. J. Arboric. 1(6):101-106.

Santamour, F.S. Jr. 1984. Wound compartmentalization in cultivars of Acer, Gleditsia, and other genera. J. Environ. Hortic. 2(4):123-125.

Shigo, A.L. 1979. Tree Decay: An Expanded Concept. Agriculture Information Bulletin No. 419. USDA Forest Service. 73 pp.

Shigo, A.L. 1983. Proper tree care. J. Arboric 9(11):285-294.

Shigo, A.L., and R. Felix. 1980. Cabling and bracing. J. Arboric. 6(1):5-9.

Shigo, A.L., and E. vH. Larson. 1969. A Photo Guide to the Patterns of Discoloration and Decay in Living Northern Hardwood Trees. Research Paper NE-127, USDA Forest Service.
Shigo, A.L., W. Shortle, and P. Garrett. 1977. Compartmentalization of discolored and decayed wood associated with injection-type wounds in hybrid poplar. J.Arboric. 3(6):114118.

Smiley, E.T. 1998. Countersinking for tree bolts. J. Arboric. 24(5):245-247.

Stobbe, H., D. Dujesiefken, and K. Schröder. 2000. Tree crown stabilization with the double-belt System Osnabrück. J. Arboric. 26(5):270-274.

Acknowledgments. The authors would like to thank The State Farm Insurance Companies Foundation for providing funding and two anonymous reviewers for suggesting valuable changes to the manuscript.

${ }^{1 *}$ Assistant Professor of Arboriculture and Urban Forestry Department of Forestry

Virginia Tech University

Blacksburg, VA 24061, U.S.

${ }^{2}$ Professor of Arboriculture and Urban Forestry

University of Massachusetts at Amherst

Holdsworth Hall

UMASS-Amherst

Amherst, MA 01003, U.S.

*Corresponding author. 
Résumé. Des systèmes de support pour les arbres ont été utilisés durant de nombreuses années afin de réduire le risque de bris imputable à des fourches faibles ou fendues, ainsi que des fissures dans les branches et les troncs. Étant donné que tout défaut qui endommage l'écorce d'un arbre permet aux processus de carie et de compartimentage de s'initier, de nouveaux systèmes de support ont été développés pour éliminer le besoin de forer des trous dans l'arbre pour leur installation. Des recherches récentes suggèrent que les nouveaux systèmes n'endommagent pas autant les parties de l'arbre que le perçage de trous, et ce étant donné que le perçage de trous blessent les arbres. Des échantillons de 20 pièces de bois qui ont eu de la quincaillerie installée auparavant ont été recueillis auprès d'arboriculteurs de la Nouvelle-Angleterre. Les échantillons reçus provenaient d'arbres perçus comme de bons compartimenteurs. De simples mesures et une analyse visuelle ont permis d'indiquer que la décoloration et la carie attribuables directement à l'installation de la quincaillerie n'apparaissent pas aussi sévère qu'anticipé (même après 37 ans dans le cas d'un échantillon). Des recherches quantitatives plus poussées en regard des aspects physiologique et mécaniques des systèmes de support sont requises afin de déterminer l'intérêt envers chaque système pour l'arboriculteur.

Zusammenfassung. Baumschutzsysteme wurden über viele Jahre genutzt, um das Risiko von Baumversagen wegen schwacher Astgabeln und Rissen in Ästen und Stämmen zu mindern. Da jede Wunde in der Rinde Fäule und Abschattungsprozesse initiiert, müssen neue Schutzsysteme entwickelt werden, um von der Notwendigkeit, während der Installation ein Loch in den Baum zu bohren, wegzukommen. Die jüngste Forschung ergab, dass die neuen Systeme keine Baumteile verletzen. Eine Probennahme von 20 Holzteilen, wo kürzlich Systeme installiert wurden, wurde von Baumpflegern in ganz New England zusammengetragen. Die Probenteile kamen von Bäumen, die gut kompartmentalisieren. Einfache Messungen und Sichtkontrollen zeigten, dass Fäule und Verfärbung in direktem Zusammenhang mit Installationen nicht so heftig wie erwartet ausfielen (sogar nach 37 Jahren bei einer Probe). Um die Nützlichkeit jedes Systems für Arboristen zu bewerten, sind mehr quantitative Untersuchungen in Bezug auf physiol. und mechanische Aspekte notwendig.

Resumen. Los sistemas de soporte han sido utilizados por muchos años para ayudar a reducir el riesgo de falla de los árboles debido a horquillas débiles y fracturas en ramas y troncos. En razón de que la herida que abre la corteza del árbol inicia los procesos descomposición y compartimentación, se han diseñado nuevos sistemas de soporte para eliminar la necesidad de taladrar agujeros durante la instalación. Se colectaron en New England 20 muestras de madera que habían tenido instalados tornillos previamente. Las muestras venían de árboles tipificados como buenos compartimentalizadores. Las mediciones simples y el análisis visual indican que la decoloración y el decaimiento atribuibles a la instalación de los tornillos, parece no ser tan severa como se esperaba (después de 37 años en una muestra). Se necesita más investigación cuantitativa en aspectos de fisiología y mecánica de los sistemas de soporte con el fin de valorar la utilidad de los mismos para los arboristas. 